\title{
The Determinant of Smoking Behaviour Among Female Worker in Southeast Asia: A Case Study Among The Philippines and Indonesian
}

Hario Megatsari ( $\sim$ hario.megatsari@fkm.unair.ac.id)

Faculty of Public Health, University of Airlangga

Agung Dwi Laksono

Ministry of Health

Riza Hayati Ifroh

Faculty of Public Health, Universitas Mulawarman

\section{Research Article}

Keywords: smoking behaviour, determinant analysis, female worker, Southeast Asia, health related behaviour

Posted Date: February 1st, 2021

DOl: https://doi.org/10.21203/rs.3.rs-151438/v1

License: (c) (i) This work is licensed under a Creative Commons Attribution 4.0 International License. Read Full License 


\section{Abstract \\ Background}

The prevalence of tobacco use in Southeast Asia communities is $56 \%$ which $15 \%$ of them are female active smokers. Several studies explain that working status, neighborhood, marital status, and education are factors that cause smoking behavior in women. A scientific study is needed to obtain valid assumptions regarding the relationship of these determinants. This study aimed to analyze the determinant of smoking behavior among female workers in the Philippines and Indonesia.

\section{Methods}

The data is processed from 2017 PDHS and use female workers in the Philippines and Indonesia as the study population. The sample size is 11,375 female workers in the Philippines and 26,712 female workers in Indonesia. Apart from smoking behavior as the dependent variable, other variables analyzed were the place of residence, age, marital, education, parity, currently pregnant, and wealth status. The analysis in the final stage uses binary logistic regression.

\section{Results}

The results show that female workers in both countries from urban areas have a higher likelihood of becoming smokers than those who live in rural areas. Age group is finding as one of the smoking behavior determinants among female workers in both countries. Female workers with long-distance marriage and married / living with a partner have a lower probability of becoming a smoker than those who have marital status in the widowed/divorced category. Education level and parity are also finding as one of the smoking behavior determinants among them. Meanwhile, pregnancy found to be a protective factor for them to become a smoker. Finally, the multivariate test results found that wealth status is also a determinant of smoking behavior for female workers in both countries.

\section{Conclusions}

It was concluded that the seven variables analyzed are the determinants of smoking behavior among female workers in the Philippines and Indonesia. The seven variables are type of place, age, marital, education, parity, pregnancy, and wealth status.

\section{Introduction}

The increasing of smoking prevalence is still a public health problem, especially among women ${ }^{1,2}$. Data from the World Health Organization (WHO) states that tobacco is one of the biggest public health threats in the world, which causes more than 8 million deaths every year. More than seven million of these deaths 
are due to smoking behavior and around 1.2 million due to exposure to secondhand smoke, with $8 \%$ of smokers is a group of young women in $2014^{2}$.

Globally, around 10 million women died from the use of tobacco products (cigarettes) between 1950 and 2000. However, The estimate to tobacco-related deaths among women in the world have the potential to more than double by $2030^{3}$. In the Southeast Asia region, as the representative developing countries (Indonesia, Malaysia, Myanmar, Philippines, Singapore, Thailand, Timor-Leste, and others) cigarette is still a major health issue ${ }^{4}$. The prevalence of tobacco use in people in the Southeast Asian region is $56 \%$, and $15 \%$ of them are women who are active smokers ${ }^{2}$.

The nicotine content in cigarettes has a more dangerous effect on women than men ${ }^{5}$. Female smokers are ten times more at risk of lung cancer, cervical cancer, and blockage of blood vessels than women who do not smoke. In addition, infertility, menstrual cycle disorders are some other health problems faced by female smokers ${ }^{6,7}$. Demographic, socio-economic, and environmental factors are other factors of smoking behavior among women ${ }^{6,8}$. Another study states that the group of pregnant women who experienced attention deficit hyperactivity disorder tended to have longer-lasting smoking behavior ${ }^{9}$.

Several determinants that affect smoking behavior in people in developing countries such as the Gender, education level, income per capita, ownership of health insurance, and occupational factors are several determinants of smoking behavior among people in developing countries such as the Philippines ${ }^{10}$. We also know that smoking behavior is because of social pressure at work, physical activity disorders, sleeping difficulties ${ }^{10,11}$. A study on smoking behavior in Indonesian women as a risk factor for breast cancer has been conducted by ${ }^{12}$. It shows, there is a statistical relationship between the smoking histories of more than 12 months with the incidence of breast cancer. Research conducted by ${ }^{6,13}$, also explains that smoking habits has a close relationship with the level of health literacy, marital status, age, and employment. This research is supported by the previous study conducted in other developing countries (South India), which shows people in remote rural areas with low literacy levels and employment status are the main factors in smoking behavior ${ }^{14}$.

Smoking behavior among women in urban areas has a statistically significant relationship with women's age, education level, type of work, and marital status ${ }^{15}$. It is known that there is a tendency for women who have a low per capita income to have a higher level of consumption, so that the tendency of women to also participate in seeking additional income through other informal jobs ${ }^{13,15}$. Based on the Maternal and Child Health Profile (2020), the number of working mothers or women in urban and rural areas do not have a big difference, namely working mothers have higher health complaints $(29.62 \%)$ than mothers who do not work $(27,32 \%)^{16}$. This is supported by previous research, which explains the type of work level and the level of knowledge of women in Indonesia have a statistical correlation in smoking families, especially in rural areas ${ }^{14,17}$. 
The increase of smoking habits in younger women and girls as an implication of the poor lifestyle patterns and smoking behavior prevention treatment can affect the level of smoking prevalence on women in the future ${ }^{11}$. Various studies have been conducted in analyzing smoking behavior on women, however, the specific content regarding the determinants of smoking behavior on women who work in developing countries such as the Philippines and Indonesia is still limited. A deeper study is needed to obtain valid and accurate statistical assumptions to provide comprehensive information to describe the social determinants of smoking behavior on women working in the two countries.

\section{Methods}

\section{Aim of study}

Based on the background description, this study aims to analyze the determinant of smoking behavior among female workers in the Philippines and Indonesia.

\section{Data Source}

The data analyzed in this study are sourced from the 2017 Philippine Demographic Data Survey (PDHS) and the 2017 Indonesian Demographic Data Survey (IDHS). The PDHS and the IDHS was part of the international Demographic and Health Survey (DHS) program conducted by the Inner City Fund (ICF). The study population is all female workers in the Philippines and Indonesia. DHS samples were taken through stratification and multistage random sampling methods. The unit of analysis in this study was female workers aged 15-49 years old. With the criteria for the unit of analysis, the weighted sample is 11,375 female workers in the Philippines and 26,712 female workers in Indonesia.

\section{Data Analysis}

Smoking behavior is the dependent variable in this study. Smoking activity is the identification of smoking habits by the respondent during the interview. There are two types of smoking activity, which are non-smoking and smoking.

The independent variables examined in this research are type of place of residence, age group, marital status, level of education, parity, current pregnancy, and status of wealth. The category of place of residence is classified into urban and rural. This categorization applies to figures for the Philippines and Indonesia. The five-year age group is divided into 7 groups, namely $15-19,20-24,25-29,30-34,35-39$, and 40-45. Marital status is classified into three classifications: long-distance marriage, married/partnerliving, and widowed/divorced. Education standard is the acknowledgment of the last certificate they have by the respondent. The degree of education is classified into 4 classifications, i.e. no education, basic, secondary and higher. Parity is the number of babies born who are alive. There are three types of parity, namely prim parous $(<1)$, multiparous $(2-4)$ and grand multiparous $(>4)$. Pregnancy is classified into two categories, namely not pregnant at present (No) and pregnant at present (Yes). 
The wealth status was based on a household-owned quintile of wealth. Households were scored on the basis of the numbers and types of things they had, from televisions to bicycles or vehicles, and the characteristics of accommodation, such as drinking water, toilets and key construction materials for the floor of the house. This score was determined using the key component analysis. National wealth quintiles were arranged on the basis of household scores for each household person and then divided into the same five groups, each accounting for $20 \%$ of the population. The wealthiest classes, namely lowest, poorest, middle, richer and richest, were divided into 5 groups.

The dependent variable being studied is a dichotomous variable, so the chi-square is used for bivariate regression at the initial level. Binary logistic regression is used in the last step to examine the determinative smoking habits of female workers in the Philippines and Indonesia because of the existence of the reliance component. The whole method of research uses the program IBM SPSS 21.

\section{Ethical Approval}

The 2017 PDHS and the 2017 IDHS have obtained ethical clearance from the National Ethics Committee in the Philippines and Indonesia. The respondents' identities have all been deleted from the dataset. Respondents have provided written approval for their involvement in the study. The researcher has obtained permission to use the 2017 IDHS data and the 2017 PDHS through the website: https://dhsprogram.com/data/new-user-registration.cfm for the purposes of this study.

\section{Results}

\section{Descriptive Analysis}

Table 1 shows descriptive statistics of female workers in the Philippines and Indonesia. Based on the type of place of residence, it can be seen that in both countries, neither smoking nor smoking are dominated by female workers who live in urban areas. Based on the age group, smoker female workers in the Philippines are dominated by the 20-24 age group, while Indonesia is dominated by the 35-39 age group.

Based on marital status, female workers in both countries are dominated by those who are married/living with partners. Meanwhile, based on education level, smoker female workers in both countries are dominated by female workers with secondary education. Based on parity, the smoker female worker in the Philippines is dominated by prim parous women, meanwhile in Indonesia dominated by multiparous women.

Based on currently pregnant status, female workers in both countries are dominated by those who are not pregnant. Finally, based on wealth status, female workers in the Philippines are dominated by women with wealth status in a richer category, meanwhile in Indonesia dominated by women with wealth status in the poorer category.

\section{Multivariate Analysis}


Table2displaystheresultsofbinarylogisticregressionofsmokingbehavioramongfemale workers in the Philippines and Indonesia. Female workers in urban Philippines are 1,299 times more likely to become smokers than female workers in rural Philippines (AOR 1,299; 95\% Cl 1,299-1,299). On the other hand, female workers in urban Indonesia are 1,503 times more likely to become smokers than female workers in rural Indonesia (AOR 1.503; 95\% Cl1.502-1.503).

Based on age group, female workers in all age group in Philippine have a higher likelihood of becoming a smoker than the 45-49 age group. Meanwhile, in Indonesia shows a more random AOR than the 45-49 age group.

Based on marital status, female workers with marital status never in union and married / living with a partner have a lower likelihood of becoming a smoker than those who have marital status in the widowed/divorced category. This condition applies to both countries, although in Indonesia the chances of female workers with a marital status of never in union and married / living with partners to become a smoker are even smaller. Education level is also found as a determinant of smoking behavior among female workers in both countries. Education level in the Philippines seems to have the possibility to become a smoker with a random pattern. Meanwhile in Indonesia, shows a tendency that the better the level of education, the less likely a female worker is to become a smoker. Based on parity, female workers in all category in Philippines and Indonesia have a lower chance of becoming a smoker than grand multiparous female workers.

Female workers who are not currently pregnant in the Philippines are 2,774 times more likely to become a smoker than female workers currently pregnant (AOR 2,774; 95\% $\mathrm{Cl} 2,772-2,776$ ). On the other hand, female workers who are not currently pregnant in Indonesia have 1,430 times more chances of becoming a smoker than female workers who are currently pregnant (AOR 1,430; 95\% Cl 1,429-1,431). This information shows that currently pregnant is a protective factor for female workers in both countries to become a smoker.

Table 2 informs that wealth status is also a determinant of smoking behavior for female workers in both countries. Wealth status in the Philippines seems to have the possibility to be a smoker with random patterns. Meanwhile, in Indonesia, there is a tendency that the better the wealth status is, the less likely it is for a female worker to become a smoker.

\section{Discussion}

The results of the analysis inform that female workers in urban areas in both countries have a higher probability of becoming smokers than those living in rural areas. The urban area is defined by ${ }^{19}$ as an area that can be seen from several aspects, including population, infrastructure, and public facilities. Thus, with various kinds of facilities in the urban area and easy access to these existing facilities, female workers have the potential to become smokers. This is in line with research conducted in Indonesia by 20 
which states that the female respondents of the study in Surabaya (one of the major cities in Indonesia) smoked 13 cigarettes a day in a day.

Other studies show similar findings from this study, such as research conducted by ${ }^{21}$ in Shanghai, stated that there are a small proportion of migrant workers in Shanghai who are female smokers. Another study in Indonesia, also shows that women living in Yogyakarta (another big city in Indonesia) compensate for their stress feelings by smoking ${ }^{22}$. Studies in China regarding female students who smoke with urban and rural backgrounds state that the prevalence of smoking students in urban settings is higher than that of smoking students in rural settings ${ }^{23}$.

The results of the study found that the age group is one of the determinants of smoking behavior among female workers in the Philippines and Indonesia. The age group of 45-49, have a smaller risk of smoking than other age groups. Human age can be divided into several periods, according to ${ }^{24}$, there are at least 8 age periods, and the 45-49 age group is an age group known as middle adulthood. At the age of 45-49, people feel in good condition, so that the relative problem does not become a psychological burden, so that the risk of smoking becomes small. This is different from the age group below which psychologically still sees a problem as a burden, so that it has the potential to engage in smoking as a coping mechanism.

Research conducted by ${ }^{25}$ supports the above statement, that there are some young women in China's Shandong Province who smoke, either with the classification of "ever smoked" or "frequently smoked" in 30 last day. Study conducted in the America by ${ }^{26}$ is in line with what was found from this study, namely that the number of female smokers is dominated by the 26-44 year age group. However, a different situation exists in Australia, ${ }^{27}$ stated that the age group categorized as middle age has a smoking prevalence rate that is quite high compared to the age groups below it.

The binary logistic regression results found that marital status is one of the determinants for female workers in the Philippines and Indonesia to become a smoker. Female workers with marital status never in union and married / living with a partner have a lower probability of becoming a smoker than those who have marital status in the widowed/divorced category. The problems faced by widowed women are increasingly complex and varied, including violence, nutritional status, and reproductive health ${ }^{28}$. The complexity of these problems can be categorized as stressful life events ${ }^{29}$ of a window which can then trigger smoking as a coping strategy ${ }^{30}$.

Research conducted in the Netherlands, widows' groups also smoke, not only conventional cigarettes, but also using electronic cigarettes ${ }^{31}$. Another study by ${ }^{32}$ which aims to shed light on one side of the contentious debate just outlined by investigating whether e-cig advertising on television and in magazines encourages adult smokers to quit. From this study, one of the findings that are in line with the research findings is that the widow group also does smoking activities. Other findings from existing research are from ${ }^{33}$, stated that the group of widows who smoke in Korea makes up nearly $10 \%$ of the researchrespondents. 
The analysis also reveals that the level of education is found to be one of the determinants of smoking behavior among female workers in the Philippines and Indonesia. A phenomenon that illustrates that a person's education level can influence his decision to smoke or not. Research conducted by ${ }^{34}$ stated that there are several aspects in the context of the level of education that affect a person's smoking behavior. Research conducted in Italy ${ }^{35}$ found that the prevalence of smoking in the group with a high level of education (university graduation) was lower than in other groups.

The phenomenon of the prevalence of female smokers with a low level of education was also found in studies in China. The study found that education level was significantly related to smoking behavior ${ }^{36}$. Another study conducted in Japan found a similar pattern, namely that in the group of female smokers, the level of education was significantly associated with current smoking behavior ${ }^{37}$. Also, research conducted by (Justus, SantAnna, Davanzo, \& Moreira, 2020) in Brazil found a similar pattern to the above research, namely that higher education levels are associated with lower smoking probability and lower daily consumption intensity.

Moreover, parity is informed as a determinant for female workers to become smokers in the two countries. This study found that female workers who were grand multiparous had a lower risk of smoking compared to other age groups. The reason the multiparous group has a low risk of smoking, among others, is because they have a strong desire and commitment not to become pregnant while pregnant, this is related in several studies, including ${ }^{39}, 40$ and ${ }^{41}$.

Research in other countries shows more or less the same pattern, including research conducted in Ireland which found that smoking rates in the grand multiparous group were quite low compared to other groups 42 . The same research results were also found by ${ }^{43}$, that multiparous women are less likely to quit on their own. Meanwhile, research conducted in Greece by ${ }^{44}$, found different things, namely that the multiparous group was less likely to quit smoking when pregnant.

The analysis result found that currently pregnant is a protective factor for female workers in the Philippine and Indonesia to become a smoker. This reinforces the concept that pregnant women who smoke have a health risk, both for the mother and for the fetus/womb. ${ }^{45}$ states that smoking during pregnancy increases the risk of health problems for developing babies, including preterm birth, low birth weight, and birth defects of the mouth and lip. Smoking during and after pregnancy also increases the risk of sudden infant death syndrome (SIDS) ${ }^{46}$ stated that the harm from cigarette smoking is primarily from carbon monoxide and tar, which contribute to the complications seen during pregnancy. Nicotine alters fetal brain development and contributes to behavioral disorders in the offspring of smokers.

Research on pregnancy and smoking behavior shows some interesting things to explore. Research conducted by ${ }^{47}$ identifies the prevalence of smoking during pregnancy, and the general result is that globally the figure is relatively small, namely $1.7 \%$. Meanwhile, the highest prevalence of smoking during pregnancy was in the European Region $(8.1 \%, 4.0-12.2)$, and the lowest prevalence of smoking during pregnancy was in the African Region $(0.8 \%, 0.0-2.2)$. Meanwhile, in China, research conducted by 48 
stated that based on their research results there are about $82.9 \%$ of smoking women quit smoking after they were pregnant, and the prevalence of smoking among pregnant women was $3.8 \%$.

The multivariate test results found that wealth status was also a determinant of smoking behavior for female workers in both countries. The poor cannot be separated from their dependence on cigarettes for several reasons, including stress relievers, cheap free time, compensation for loneliness, separation, or termination of employment ${ }^{49}$. The Truth Initiative, one of the NGOs engaged in tobacco control, states that the causes of the poor are still caused by the programs developed by the cigarette industry, including the proliferation of cigarette sales places, massive cigarette advertisements, and cheap cigarette prices 50 .

Research conducted by ${ }^{51}$ stated that living in a poorer environment presents a unique risk for smoking among adults aged 30 to 39 years and over. Other studies in China also produced the same findings, ${ }^{52}$ stating that the lower the socio-economic conditions of the respondents, the higher the prevalence of smoking. Research by comparing several countries conducted by ${ }^{53}$ also shows a pattern, namely that the lower the socioeconomic level of a group, the higher the smoking behavior level of that group.

\section{Conclusions}

Based on the research results, it can be concluded that the 7 variables analyzed were determinants of smoking behavior among female workers in Philippine and Indonesia. The seven variables are type of place of residence, age group, marital status, education level, parity, currently pregnant, and wealth status.

\section{Declarations}

Ethics approval and consent to participate: Not applicable

Consent for publication: Not applicable

Availability of data and materials: All data generated or analyzed during this study are included in this published article

Competing interests: The authors declare that they have no competing interests

\section{Funding: Nil}

Authors' contributions: $\mathrm{HM}$ and $\mathrm{ADL}$ conceived of the presented idea. ADL developed the theory and performed the computations. $\mathrm{HM}$ and $\mathrm{RHI}$ verified the analytical methods. $\mathrm{ADL}$ and $\mathrm{RH}$ interpreted the data. HM and ADL drafted the manuscript and substantively revise it. All authors discussed the results and contributed to the final manuscript.

Acknowledgements: The authors are grateful to the U.S. Agency for International Development (USAID) for providing the data as material for analysis in this study. 


\section{References}

1. Madureira J, Camelo A, Silva Al, Reis AT, Esteves F, Ribeiro Al, et al. The importance of socioeconomic position in smoking, cessation and environmental tobacco smoke exposure during pregnancy. Sci Rep. 2020;10(1):15584.

2. World Health Organization. WHO global report on trends in prevalence of tobacco use third edition. Geneva, Switzerland: World Health Organization; 2019. 121 p.

3. Kalan ME, Taleb Z Ben. Waterpipe tobacco smoking: A reality or hidden iceberg for Iranian women. Heal Promot Perspect. 2018;8(4):252-4.

4. Islami F, Torre LA, Jemal A. Global trends of lung cancer mortality and smoking prevalence. Transl Lung Cancer Res. 2015;4(4):327-38.

5. Liu S, Zhang M, Yang L, Li Y, Wang L, Huang Z, et al. Prevalence and patterns of tobacco smoking among Chinese adult men and women: Findings of the 2010 national smoking survey. $J$ Epidemiol Community Health. 2017;71(2):154-61.

6. Reitan T, Callinan S. Changes in smoking rates among pregnant women and the general female population in Australia, Finland, Norway, and Sweden. Nicotine Tob Res. 2017;19(3):282-9.

7. Sisler L, Meernik C, Ripley-Moffitt C, Greyber J, Goldstein AO. Case Study: Use of Electronic Nicotine Delivery Systems (ENDS) By a Pregnant Woman. J Smok Cessat. 2017;12(3):139-42.

8. Tabb KM, Malinga T, Wang Y, Kelly K, Meline B, Huang H. Prevalence and Correlates of Tobacco Smoking During the Perinatal Period Among Women Enrolled in a Midwestern WIC Program. 2020; (0123456789).

9. Andersson A, Hegvik T, Chen Q, Rosenqvist MA, Kvalvik G, Almqvist C, et al. Attention-deficit / hyperactivity disorder and smoking habits in pregnant women. PLoS One. 2020;69(June):1-13.

10. Kashiwagi S. Relation between Smoking Habits and Self-Rated Health of Older Persons in the Philippines: Evidence-Based Tobacco Policy Advocacy. Open J Polit Sci. 2017;07(04):488-500.

11. Solomon A. Gender, women, and the future of tobacco control. In: Drugs and Alcohol Today. 2020. p. $249-62$.

12. Nindrea RD, Kusnanto H, Haryono SJ, Harahap WA, Dwiprahasto I, Lazuardi L, et al. Development of Breast Cancer Risk Prediction Model for Women in Indonesia: A Case-Control Study. Research Square. 2020.

13. Michalek AK, Wong SL, Brown-johnson CG, Prochaska JJ. Smoking and Unemployment: A Photo Elicitation Project. 2020;1-7.

14. Vinothkumar G, Girija G, Manikandan M, Vincent A, Newtonraj A. Prevalence and determinants of tobacco use in a remote rural area of South India: a community based cross sectional study. Int $\mathrm{J}$ Community Med Public Heal. 2020;7(9):3499-503.

15. Mishra GA, Kulkarni S V., Gupta SD, Shastri SS. Smokeless tobacco use in Urban Indian women: Prevalence and predictors. Indian J Med Paediatr Oncol. 2015;36(3):176-82.

16. Badan Pusat Statistik RI. Profil Kesehatan Ibu dan Anak. 2020. 
17. Nadhiroh SR, Djokosujono K, Utari DM. Socioeconomic characteristics, paternal smoking and secondhand tobacco smoke exposure among infants in Jakarta, Indonesia. Tob Induc Dis. 2020;18(May):1-9.

18. Wulandari RD, Qomarrudin MB, Supriyanto S, Laksono AD. Socioeconomic Disparities in Hospital Utilization among Elderly People in Indonesia. Indian J Public Heal Res Dev. 2019;10(11):1800-4.

19. Dijkstra L, Hamilton E, Lall S, Wahba S. How do we define cities, towns, and rural areas? [Internet]. 2020 [cited 2021 Jan 13]. Available from: https://blogs.worldbank.org/sustainablecities/how-do-wedefine-cities-towns-and-rural-areas

20. Hardesty JJ, Kaplan B, Martini S, Megatsari H, Kennedy RD, Cohen JE. Smoking among female daily smokers in Surabaya, Indonesia. Public Health. 2019;172.

21. Liu $Y$, Song $H$, Wang $T$, Wang $T$, Yang $H$, Gong J, et al. Determinants of tobacco smoking among ruralto-urban migrant workers: a cross-sectional survey in Shanghai. BMC Public Health [Internet]. 2015;15(1):131. Available from: https://doi.org/10.1186/s12889-015-1361-x

22. Hidayatullah RA DA. HUBUNGAN ANTARA STRES PSIKOSOSIAL DENGAN PERILAKU MEROKOK PADA WANITA [Internet]. Universitas Mercu Buana Yogyakarta, Indonesia; 2017. Available from: http://eprints.mercubuana-yogya.ac.id/id/eprint/1619

23. Ho MG, Ma S, Chai W, Xia W, Yang G, Novotny TE. Smoking among rural and urban young women in China. Tob Control [Internet]. 2010 Feb 1;19(1):13 LP - 18. Available from: http://tobaccocontrol.bmj.com/content/19/1/13.abstract

24. Valentine-French ML\& S. Book: Lifespan Development - A Psychological Perspective (Lally and Valentine-French) [Internet]. 2020. Available from: https://chem.libretexts.org/@go/page/10172

25. Dong X, Ding M, Chen W, Liu Z, Yi X. Relationship between smoking, physical activity, screen time, and quality of life among adolescents. Int J Environ Res Public Health. 2020;17(21):1-15.

26. Nighbor TD, Doogan NJ, Roberts ME, Cepeda-Benito A, Kurti AN, Priest JS, et al. Smoking prevalence and trends among a U.S. national sample of women of reproductive age in rural versus urban settings. PLoS One [Internet]. 2018 Nov 28;13(11):e0207818. Available from: https://journals.plos.org/plosone/article/citation?id=10.1371/journal.pone.0207818

27. Scollo M, Greenhalgh E. Tobacco in Australia: Facts and issues [Internet]. Tobacco in Australia: Facts and issues. 2020. 74-92 p. Available from: https://www.tobaccoinaustralia.org.au/home.aspx

28. Nations U. Invisible Women, Invisible Problems [Internet]. 2020 [cited 2021 Jan 14]. Available from: https://www.un.org/en/observances/widows-day

29. Carlson D. Stressful Life Events. In: Michalos AC, editor. Encyclopedia of Quality of Life and WellBeing Research [Internet]. Dordrecht: Springer Netherlands; 2014. p. 6362-4. Available from: https://doi.org/10.1007/978-94-007-0753-5_2880

30. Tamers SL, Okechukwu C, Marino M, Guéguen A, Goldberg M, Zins M. Effect of stressful life events on changes in smoking among the French: longitudinal findings from GAZEL. Eur J Public Health [Internet]. 2015/03/11. 2015 Aug;25(4):711-5. Available from:

https://pubmed.ncbi.nlm.nih.gov/25762691

Page $11 / 17$ 
31. Schoren C, Hummel K, de Vries H. Electronic cigarette use: comparing smokers, vapers, and dual users on characteristics and motivational factors. Tob Prev Cessat [Internet]. 2017 Apr 1;3:8. Available from: https://pubmed.ncbi.nlm.nih.gov/32432183

32. Dave D, Dench $D$, Grossman M, Kenkel DS, Saffer H. Does e-cigarette advertising encourage adult smokers to quit? J Health Econ [Internet]. 2019;68:102227. Available from: http://www.sciencedirect.com/science/article/pii/S0167629619301870

33. Kang E, Lee JA, Cho H-J. Characteristics of hardcore smokers in South Korea from 2007 to 2013. BMC Public Health [Internet]. 2017;17(1):521. Available from: https://doi.org/10.1186/s12889-017$4452-z$

34. Maralani V. Understanding the links between education and smoking. Soc Sci Res [Internet]. 2014;48:20-34. Available from: http://dx.doi.org/10.1016/j.ssresearch.2014.05.007

35. Madonia G, Davi\&\#039; M, Madonia U, Taormina E, Miciletto S, Impellizzeri F, et al. Education level and smoking. Eur Respir J [Internet]. 2011 Sep 1;38(Suppl 55):p4237. Available from: http://erj.ersjournals.com/content/38/Suppl_55/p4237.abstract

36. Wang Q, Shen JJ, Sotero M, Li CA, Hou Z. Income, occupation and education: Are they related to smoking behaviors in China? PLoS One [Internet]. 2018 Feb 8;13(2):e0192571. Available from: https://doi.org/10.1371/journal.pone.0192571

37. Tomioka K, Kurumatani N, Saeki K. The Association Between Education and Smoking Prevalence, Independent of Occupation: A Nationally Representative Survey in Japan. J Epidemiol [Internet]. 2019/03/02. 2020 Mar 5;30(3):136-42. Available from: https://pubmed.ncbi.nlm.nih.gov/30828035

38. Justus M, Sant_Anna EG, Davanzo ES, Moreira GC. Education and smoking behavior in Brazil: decision to smoke and daily cigarette consumption intensity. Nov Econ [Internet]. 2020;30:679-700. Available from: http://www.scielo.br/scielo.php?script=sci_arttext\&pid=S010363512020000200679\&nrm=iso

39. Diamanti A, Raftopoulos V, Lykeridou K, Schoretsaniti S, Gratziou C, Katsaounou P. The smoking status and knowledge of pregnant smokers in Greece. Eur Respir J [Internet]. 2017 Sep 1;50(suppl 61):PA1265. Available from: http://erj.ersjournals.com/content/50/suppl_61/PA1265.abstract

40. Motoc NS, Vancea R, Vaida Voevod DA, Rajnoveanu R, Chis A, Man MA. Smoking during pregnancy: a survey of women "knowledge" and behavior. Eur Respir J [Internet]. 2019 Sep 28;54(suppl 63):PA4471. Available from: http://erj.ersjournals.com/content/54/suppl_63/PA4471.abstract

41. Oechsle A, Wensing M, Ullrich C, Bombana M. Health Knowledge of Lifestyle-Related Risks during Pregnancy: A Cross-Sectional Study of Pregnant Women in Germany. Int J Environ Res Public Health [Internet]. 2020 Nov 20;17(22):8626. Available from: https://pubmed.ncbi.nlm.nih.gov/33233790

42. Reynolds CME, Egan B, McKeating A, Daly N, Sheehan SR, Turner MJ. Five year trends in maternal smoking behaviour reported at the first prenatal appointment. Irish J Med Sci (1971 -) [Internet]. 2017;186(4):971-9. Available from: https://doi.org/10.1007/s11845-017-1575-2

43. Balázs P, Grenczer A, Rákóczi I, Foley KL. Continued smoking versus spontaneous quitting among pregnant women living in a high risk environment. Cent Eur J Public Health. 2018;26(3):164-70. 
44. Tsakiridis I, Mamopoulos A, Papazisis G, Petousis S, Liozidou A, Athanasiadis A, et al. Prevalence of smoking during pregnancy and associated risk factors: a cross-sectional study in Northern Greece. Eur J Public Health [Internet]. 2018 Apr 1;28(2):321-5. Available from: https://doi.org/10.1093/eurpub/cky004

45. CDC. Substance Use During Pregnancy [Internet]. 2020 [cited 2021 Jan 16]. Available from: https://www.cdc.gov/reproductivehealth/maternalinfanthealth/substance-abuse/substance-abuseduring-pregnancy.htm\#: :text=Smoking during pregnancy increases the,infant death syndrome (SIDS).

46. McDonnell BP, Regan C. Smoking in pregnancy: pathophysiology of harm and current evidence for monitoring and cessation. Obstet Gynaecol [Internet]. 2019 Jul 1;21(3):169-75. Available from: https://doi.org/10.1111/tog.12585

47. Lange S, Probst C, Rehm J, Popova S. National, regional, and global prevalence of smoking during pregnancy in the general population: a systematic review and meta-analysis. Lancet Glob Heal [Internet]. 2018;6(7):e769-76. Available from:

http://www.sciencedirect.com/science/article/pii/S2214109X18302237

48. Xu X, Rao Y, Wang L, Liu S, Guo JJ, Sharma M, et al. Smoking in pregnancy: a cross-sectional study in China. Tob Induc Dis [Internet]. 2017;15(1):35. Available from: https://doi.org/10.1186/s12971017-0140-0

49. Peretti-Watel P, Constance J. "It's all we got left". Why poor smokers are less sensitive to cigarette price increases. Int J Environ Res Public Health [Internet]. 2009/02/10. 2009 Feb;6(2):608-21. Available from: https://pubmed.ncbi.nlm.nih.gov/19440404

50. Truth Initiative. Why are $72 \%$ of smokers from lower-income communities? [Internet]. Truth Initiative. 2018 [cited 2021 Jan 17]. Available from: https://truthinitiative.org/research-resources/targetedcommunities/why-are-72-smokers-lower-income-communities

51. Cambron C, Kosterman R, Hawkins JD. Neighborhood Poverty Increases Risk for Cigarette Smoking From Age 30 to 39. Ann Behav Med [Internet]. 2019 Aug 16;53(9):858-64. Available from: https://doi.org/10.1093/abm/kay089

52. Wang X, Zhang T, Wu J, Yin S, Nan X, Du M, et al. The Association between Socioeconomic Status, Smoking, and Chronic Disease in Inner Mongolia in Northern China. Int J Environ Res Public Health [Internet]. 2019 Jan 9;16(2):169. Available from: https://pubmed.ncbi.nlm.nih.gov/30634452

53. Abdulrahim S, Jawad M. Socioeconomic differences in smoking in Jordan, Lebanon, Syria, and Palestine: A cross-sectional analysis of national surveys. PLoS One [Internet]. 2018 Jan 30;13(1):e0189829. Available from: https://doi.org/10.1371/journal.pone.0189829

\section{Tables}


Table 1

Descriptive statistics of female workers in Philippine and Indonesia in 2017

\begin{tabular}{|c|c|c|c|c|c|c|}
\hline \multirow[t]{3}{*}{ Variables } & \multicolumn{3}{|c|}{$\begin{array}{l}\text { Philippine } \\
(n=11,375)\end{array}$} & \multicolumn{3}{|c|}{$\begin{array}{l}\text { Indonesia } \\
(n=26,712)\end{array}$} \\
\hline & \multicolumn{3}{|c|}{ Smoking Behaviour } & \multicolumn{3}{|c|}{ Smoking Behaviour } \\
\hline & No & Yes & p & No & Yes & p \\
\hline Type of place of residence & & & $\star \star \star 0.000$ & & & $\star \star \star 0.000$ \\
\hline - Urban & $51.8 \%$ & $57.8 \%$ & & $52.8 \%$ & $54.2 \%$ & \\
\hline • Rural & $48.2 \%$ & $42.2 \%$ & & $47.2 \%$ & $45.8 \%$ & \\
\hline Age group & & & $* * * 0.000$ & & & $\star \star \star 0.000$ \\
\hline$\cdot 15-19$ & $4.8 \%$ & $4.6 \%$ & & $6.7 \%$ & $1.8 \%$ & \\
\hline$\cdot 20-24$ & $15.4 \%$ & $19.3 \%$ & & $12.4 \%$ & $8.3 \%$ & \\
\hline$\cdot 25-29$ & $15.7 \%$ & $14.7 \%$ & & $13.5 \%$ & $9.0 \%$ & \\
\hline$\cdot 30-34$ & $14.3 \%$ & $17.3 \%$ & & $15.0 \%$ & $14.6 \%$ & \\
\hline$\cdot 35-39$ & $18.0 \%$ & $16.7 \%$ & & $17.9 \%$ & $23.8 \%$ & \\
\hline$\cdot 40-44$ & $15.6 \%$ & $13.8 \%$ & & $17.6 \%$ & $19.7 \%$ & \\
\hline$\cdot 45-49$ & $16.1 \%$ & $13.7 \%$ & & $16.9 \%$ & $22.8 \%$ & \\
\hline Marital status & & & $\star * \star 0.000$ & & & $\star * \star 0.000$ \\
\hline - Never in union & $28.4 \%$ & $34.0 \%$ & & $18.0 \%$ & $10.4 \%$ & \\
\hline - Married/Living with partner & $65.3 \%$ & $56.4 \%$ & & $75.4 \%$ & $68.8 \%$ & \\
\hline - Widowed/Divorced & $6.3 \%$ & $9.6 \%$ & & $6.6 \%$ & $20.7 \%$ & \\
\hline Education Level & & & $\star \star \star 0.000$ & & & $\star * \star 0.000$ \\
\hline - No education & $0.8 \%$ & $0.4 \%$ & & $1.9 \%$ & $8.4 \%$ & \\
\hline • Primary & $12.8 \%$ & $16.4 \%$ & & $29.0 \%$ & $35.1 \%$ & \\
\hline - Secondary & $39.5 \%$ & $44.3 \%$ & & $49.4 \%$ & $45.8 \%$ & \\
\hline • Higher & $46.8 \%$ & $38.9 \%$ & & $19.6 \%$ & $10.7 \%$ & \\
\hline Parity & & & $\star * \star 0.000$ & & & $* * * 0.000$ \\
\hline - Prim parous & $47.6 \%$ & $46.5 \%$ & & $43.4 \%$ & $34.8 \%$ & \\
\hline
\end{tabular}

Note: ${ }^{*} p<0.05 ; *{ }^{*} p<0.01 ; * * * p<0.001$ 


\begin{tabular}{|c|c|c|c|c|c|c|}
\hline \multirow[t]{3}{*}{ Variables } & \multicolumn{3}{|c|}{$\begin{array}{l}\text { Philippine } \\
(n=11,375)\end{array}$} & \multicolumn{3}{|c|}{$\begin{array}{l}\text { Indonesia } \\
(n=26,712)\end{array}$} \\
\hline & \multicolumn{3}{|c|}{ Smoking Behaviour } & \multicolumn{3}{|c|}{ Smoking Behaviour } \\
\hline & No & Yes & $\mathbf{p}$ & No & Yes & p \\
\hline - Multiparous & $40.9 \%$ & $38.2 \%$ & & $51.3 \%$ & $51.1 \%$ & \\
\hline - Grand multiparous & $11.5 \%$ & $15.2 \%$ & & $5.3 \%$ & $14.1 \%$ & \\
\hline Currently pregnant & & & & & & $\star \star * 0.000$ \\
\hline - No & $97.4 \%$ & $99.1 \%$ & & $97.0 \%$ & $98.4 \%$ & \\
\hline - Yes & $2.6 \%$ & $0.9 \%$ & & $3.0 \%$ & $1.6 \%$ & \\
\hline Wealth status & & & $\star * \star 0.000$ & & & $\star \star \star 0.000$ \\
\hline - Poorest & $13.4 \%$ & $14.4 \%$ & & $16.4 \%$ & $26.1 \%$ & \\
\hline - Poorer & $16.4 \%$ & $16.9 \%$ & & $17.2 \%$ & $19.6 \%$ & \\
\hline - Middle & $19.1 \%$ & $19.4 \%$ & & $19.6 \%$ & $18.6 \%$ & \\
\hline - Richer & $22.7 \%$ & $26.3 \%$ & & $22.0 \%$ & $18.6 \%$ & \\
\hline - Richest & $28.5 \%$ & $23.0 \%$ & & $24.8 \%$ & $17.1 \%$ & \\
\hline
\end{tabular}


Table 2

The result of binary logistic regression of smoking behaviour among female workers in Philippine and Indonesia in 2017

\begin{tabular}{|c|c|c|c|c|c|c|}
\hline \multirow[t]{4}{*}{ Predictors } & \multicolumn{6}{|c|}{ Smoking Behaviour } \\
\hline & \multirow{2}{*}{\multicolumn{3}{|c|}{$\begin{array}{l}\text { Philippine } \\
(n=11,375)\end{array}$}} & \multirow{2}{*}{\multicolumn{3}{|c|}{$\begin{array}{l}\text { Indonesia } \\
(n=26,712)\end{array}$}} \\
\hline & & & & & & \\
\hline & AOR & LB & UB & AOR & LB & UB \\
\hline Type of place of residence: Urban & $\star \star \star 1.299$ & 1.299 & 1.299 & $\star \star \star 1.503$ & 1.502 & 1.503 \\
\hline Type of place of residence: Rural & - & - & - & - & - & - \\
\hline Age group: 15-19 & $\star \star \star 1.105$ & 1.105 & 1.106 & $\star \star \star 0.251$ & 0.251 & 0.251 \\
\hline Age group: $20-24$ & $\star \star \star 1.809$ & 1.808 & 1.810 & $\star \star \star 0.684$ & 0.683 & 0.684 \\
\hline Age group: $25-29$ & $\star \star \star 1.425$ & 1.424 & 1.425 & $\star \star \star 0.731$ & 0.731 & 0.731 \\
\hline Age group: $30-34$ & $\star \star \star 1.823$ & 1.822 & 1.823 & $\star \star \star 1.039$ & 1.039 & 1.039 \\
\hline Age group: $35-39$ & $\star \star \star * 1.305$ & 1.305 & 1.306 & $\star * * 1.306$ & 1.305 & 1.306 \\
\hline Age group: $40-44$ & $\star \star \star 1.113$ & 1.113 & 1.113 & $\star * \star 0.968$ & 0.968 & 0.968 \\
\hline Age group: $45-49$ & - & - & - & - & - & - \\
\hline Marital: Never in union & $\star \star \star 0.989$ & 0.989 & 0.990 & $\star \star \star 0.378$ & 0.378 & 0.378 \\
\hline Marital: Married/Living with partner & $\star \star \star 0.568$ & 0.568 & 0.568 & $\star * \star 0.320$ & 0.320 & 0.320 \\
\hline Marital: Widowed/Divorced & - & - & - & - & - & - \\
\hline Education: No education & $\star \star \star 0.640$ & 0.639 & 0.641 & $\star \star \star 4.576$ & 4.574 & 4.578 \\
\hline Education: Primary & $\star \star \star 1.686$ & 1.685 & 1.686 & $\star \star \star 1.526$ & 1.526 & 1.526 \\
\hline Education: Secondary & $\star \star \star 1.400$ & 1.400 & 1.400 & $\star \star \star 1.515$ & 1.514 & 1.515 \\
\hline Education: Higher & - & - & - & - & - & - \\
\hline Parity: Prim parous & $\star \star \star 0.493$ & 0.493 & 0.493 & $\star \star \star 0.530$ & 0.529 & 0.530 \\
\hline Parity: Multiparous & $\star \star \star 0.675$ & 0.675 & 0.675 & $\star \star \star 0.481$ & 0.481 & 0.481 \\
\hline Parity: Grand multiparous & - & - & - & - & - & - \\
\hline Currently pregnant: No & $\star \star \star 2.774$ & 2.772 & 2.776 & $\star * \star 1.430$ & 1.429 & 1.431 \\
\hline Currently pregnant: Yes & - & - & - & - & - & - \\
\hline Wealth: Poorest & $\star \star \star 1.106$ & 1.106 & 1.106 & $\star \star \star 1.906$ & 1.905 & 1.906 \\
\hline
\end{tabular}

Note: $95 \%$ Confidence Interval; ${ }^{*} \mathrm{p}<0.05 ; * * \mathrm{p}<0.01 ; * * * \mathrm{p}<0.001$ 


\begin{tabular}{|c|c|c|c|c|c|c|}
\hline \multirow[t]{4}{*}{ Predictors } & \multicolumn{6}{|c|}{ Smoking Behaviour } \\
\hline & \multirow{2}{*}{\multicolumn{3}{|c|}{$\begin{array}{l}\text { Philippine } \\
(n=11,375)\end{array}$}} & \multirow{2}{*}{\multicolumn{3}{|c|}{$\begin{array}{l}\text { Indonesia } \\
(n=26,712)\end{array}$}} \\
\hline & & & & & & \\
\hline & AOR & LB & UB & AOR & LB & UB \\
\hline Wealth: Poorer & $\star \star \star 1.118$ & 1.118 & 1.118 & $\star \star * 1.586$ & 1.586 & 1.587 \\
\hline Wealth: Middle & $\star \star \star 1.129$ & 1.129 & 1.129 & $\star \star \star 1.311$ & 1.311 & 1.312 \\
\hline Wealth: Richer & $\star * \star 1.388$ & 1.387 & 1.388 & $\star \star \star 1.145$ & 1.145 & 1.145 \\
\hline Wealth: Richest & - & - & - & - & - & - \\
\hline
\end{tabular}

